pronounced rises took place in Germany and most of the other belligerent countries. Even some of the neutral countries showed a distinct reaction, which in the case of Switzerland was more marked than that of England and Wales.

\section{Rehabilitation of Adult Prostitutes}

Experience shows that the problem of prostitution tends to acquire particular importance in time of war, not only for the countries directly involved but also for other countries, and the publication by the League of Nations Secretariat of a third and concluding volume of studies on this subject is therefore opportune (League of Nations Pamphlet, iv, 4, Messrs. Allen and Unwin, 40 Museum Street, London, W.C.1 ; 1939. 3s. 6d. net). An endeavour is made in this volume to elucidate the controversial question of possibilities of reclaiming prostitutes for re-entry into the normal life of the community. Institutional training is discussed at some length, and an account is given of the different approaches made by various types of institutions, religious and lay, to the problem. The Advisory Committee which studied this question came to the conclusion that, if certain principles are applied and certain psychological factors recognized, rehabilitation of adult prostitutes is, within limits, both feasible and successful. The volume should be useful not only to those directly concerned with the problem of rehabilitation, but also to all social workers who have to deal with the very complex question of prostitution in general.

\section{London School of Hygiene and Tropical Medicine}

The report for 1938-39 of the London School of Hygiene and Tropical Medicine, incorporating the Ross Institute, is, as usual, of great interest. It should be realized that studies which seem minute and insignificant, such as the survival and fertility of insects under highly unfavourable conditions, may be of the utmost importance to planters and owners of big estates. They should subscribe more generously to a School which does so much for their welfare. The Institute, while busy at home with many discoveries, including bacterial survival for well over a century, has been continuing the attack on the problems of Anopheles minimus in Assam, a mosquito which can be controlled more effectively by shading than by the use of drugs.

It is very satisfactory to learn that in the chief field stations of tea estates in India it has been possible to train a staff of Indians as surveyors of malaria and laboratory assistants. The annual malaria control course for laymen which started at the Institute in 1929 is free, and from small beginnings has now attracted more than a thousand learners. Ceylon has had in the past great outbreaks of malaria due to drought, but the failure of two monsoons during the year under survey did not lead to the major outbreak that might have been expected. The Ceylon Government and the Estates Malaria Control scheme confined the trouble to minor eruptions. This is a specimen of the remarkable work that is done.
The energies of the Institute are, indeed, far flung. They have been extended to the Gold Coast and the question of mass emigration of refugees from Central Europe to British Guiana. Dr. Chester Beatty's speech at the annual 'Mosquito Day' luncheon dwelt rightly on the comparatively meagre support given. Some of the travelling specialists are constantly employed and clearly overworked.

\section{A New Type of Wood-Burning Stove}

A NEW stove, developed by the Connecticut Forest and Park Association in co-operation with Prof. L. E. Seeley, heating expert of Yale University, burns wood with an efficiency estimated at ninety per cent. It is capable of heating two or three rooms and requires filling only once or twice a day. A report issued by Science Service, of Washington, D.C., says that the new heater holds about two and a quarter cubic feet of wood, or slightly more than $50 \mathrm{lb}$. It is estimated that it will generate about 40,000 B.T.U./hr. for an eight-hour period without attention. This amount of heat is sufficient for two or three rooms in cold weather. In mild weather the heater will easily run more than twenty-four hours without attention.

The new heater differs radically in design from the usual type of wood-burning stove. Air supply is limited as in any tight heater, but all air is not directed into one space, as is customary; instead, provision is made for pre-determined amounts of air to enter the combustion chamber, while a separate air supply is allowed to mix with the highly heated gases formed by the burning wood. The wood gases are passed through small passage-ways called combustion ports where they are burned separately from the wood. The process is a partial distillation of the wood producing charcoal and gas, and the products are burned in different spaces. The result is high efficiency with a minimum of loss in soot, creosote and ash. The Governor of Connecticut, who has expressed interest in the establishment of a permanent outlet for the firewood now being wasted in the State for lack of a market, has made possible a small-scale commercial experiment in the use of wood as fuel in State institutions.

\section{Electrical Thawing}

DURING the recent cold spell, serious inconvenience has been caused in many households by the freezing of water services. In the Electrical Review of February 2, a letter from Mr. C. W. Salt, the city electrical engineer to Carlisle, is published describing an effective and 'easily applied method of thawing frozen water services, when a public A.C. supply is available. In Carlisle, where the voltage is 230 , a double-wound single-phase transformer is used, the ratio being $230 / 12$, with a regulating resistance on the primary side and an ammeter scaled $0-250$ on the secondary side. The primary is plugged into a 15 amp. radiator socket and the secondary leads are attached to a tap or pipe inside the house and to the stopcock of a neighbouring house. The regulating resistance is adjusted until the secondary current flows through 
the frozen pipe at about $150 \mathrm{amp}$. It is found that the normal $\frac{1}{2}$-in. lead service pipe thaws out in five to seven minutes. Mr. Salt says that in cases of sickness where there is no water supply and consequently no kitchen fire or other means of providing hot water, this remedy has been much appreciated.

\section{New Physical Apparatus}

Prof. C. J. Overbeck of Evanston University, Illinois, directs attention to some of the recent improvements in apparatus for physical research developed in the United States during the last four years, in a twelve-page illustrated article in the January issue of the Journal of Scientific Instruments. He deals with fractionating oil-diffusion pumps of both glass and metal and with the use of sylphon (metal bellows) for producing adjustments in evacuated spaces from outside without interfering with the vacuum. He describes a centrifuge suspended and run in a vacuum, a new apparatus for determining $e / m$ for electrons, and a device for renewing the emitting surface of an oxide cathode. The Bureau of Standards apparatus for attaching to free balloons which signals its records and weighs only $5 \mathrm{lb}$. is also mentioned. Some examples of the use of Polaroid for stress analysis are given, and a vacuum grating spectrograph for investigating infra-red rotation spectra is described. The advantages of the new synthetic lithium fluoride crystals combined with quartz in a lens doublet, achromatic over a wide range of wave-lengths, are illustrated by spectrograms. References to thirty-one sources of further information are given, and Strong's "Procedures in Experimental Physics" (New York, 1938) is mentioned as of great value for its up-to-date laboratory devices.

\section{Seedlings in Transit : a New Method}

ScIEnce Service, of Washington, D.C., reports the extensive use of a new and simple method of protecting young seedlings of tomato and cabbage from drying out during transit, which may have considerable importance in Great Britain at the present time. Dr. R. N. Du Puis of Chicago suggested that the plants might survive better if the sphagnum in which the roots were wrapped were moistened with a glycerine solution instead of with water. After encouraging large-scale experiments in 1939, the method was brought into commercial use, more than 75 million seedlings being shipped from the south to the north under these conditions. The new mothod apparently saved much loss from drying out and is also stated to give protection against fungus troubles.

\section{The National Book Council}

IT was a wise statesman who said that we must educate our masters, the democracy of to-day, and the National Book Council's latest report, 1938-39, is full of a well-backed forward movement with a new Consultative Committee designed to promote more book-reading. At present, the public libraries are used by about 15 per cent of the population, which remain in ignorance of the chances they have to improve their knowledge, or at least get sound information about their hobbies and the special line of reading they prefer. "Four to Fourteen" for young people has already become a standard bibliography, and "Summer Holiday Reading", a select list of new books, has led to demands beyond the large number printed. Such guides through the present overgrown jungle of books are essential to-day.

The 38-page "Catalogue of Books for the Services" is a good and wisely catholic selection, due to the Council and the Society of Authors acting together. It gives learned and popular theology on one page and on another a choice of thrillers by Dorothy Sayers, science, plays, essays, and fiction, old as well as new. We notice one omission in the judicious section of poetry; Kipling's two early books of soldier jingles are included, but where is the "Collected Verse" of his more mature years ? That volume holds many well-known pieces and celebrates the work of our Navy with the "Wet Litany", "Mine Sweepers", "The North Sea Patrol" and other vivid things not easily forgotten. Evacuees, both young and adult, have raised new problems of booksupply, in towns and villages unequal to the demand, and the Council has suggested to the Board of Education sound plans to arouse interest and supply the books needed.

\section{Earthquakes in Greece}

STrong earthquakes were experienced last week in the town of Ekaterini at the foot of Mount Olympus on the shores of the Gulf of Salonica in Greece. On the morning of February 1, several tremors and one or two earthquakes occurred to the accompaniment of loud and long-continued underground rumbling. Some houses collapsed. On February 2 the shocks continued, there being eighteen in all. About 120 buildings, including some schools, the law courts and the post office, collapsed or became severely damaged. The casualty numbers have not yet been published. Tents have been erected as temporary dwellings and the postal headquarters are reported to be temporarily in a tent. Medical supplies and anti-typhoid vaccines have been sent from Salonica. It will be remembered that a severe earthquake wrecked several villages in the Chalcidice district of Greece on the night of September 27-28, 1932. The epicentre was then estimated to have been between Salonica and Mount Athos (Nature, October 8, 1932 , p. 537), which is to the north-east of the present epicentres.

\section{Earth Tremors in Scotland}

SLIGHT earth tremors are reported to have occurred on February 3 at Stirling in Scotland. No damage has been done. The tremors may have been occasioned by slipping along a local fault. Similar tremors were reported from Roslin, near Edinburgh, on February 10, 1934, though the most active region seismically in Scotland is near Comrie in Perthshire, where the slight tremors are considered to be due to slipping along the Highland Boundary Fault system. 